'New dimensions of commercial banks' corporate social responsibility in the Visegrád Group countries"

\begin{tabular}{|c|c|}
\hline AUTHORS & $\begin{array}{l}\text { Csaba Lentner } \text { https://orcid.org/0000-0003-2241-782X } \\
\mathbb{R} \text { http://www.researcherid.com/rid/J-2382-2016 } \\
\text { Vitéz Nagy } \mathbb{D} \text { http://orcid.org/0000-0002-1310-7646 } \\
\mathbb{R} \text { http://www.researcherid.com/rid/AAL-1509-2020 }\end{array}$ \\
\hline ARTICLE INFO & $\begin{array}{l}\text { Csaba Lentner and Vitéz Nagy (2020). New dimensions of commercial banks' } \\
\text { corporate social responsibility in the Visegrád Group countries. Banks and Bank } \\
\text { Systems, } 15(2), 138-152 \text {. doi:10.21511/bbs.15(2).2020.13 }\end{array}$ \\
\hline DOI & http://dx.doi.org/10.21511/bbs.15(2).2020.13 \\
\hline RELEASED ON & Tuesday, 09 June 2020 \\
\hline RECEIVED ON & Friday, 17 April 2020 \\
\hline ACCEPTED ON & Monday, 01 June 2020 \\
\hline LICENSE & $\begin{array}{l}(c) \text { EY } \\
\text { This work is licensed under a Creative Commons Attribution } 4.0 \text { International } \\
\text { License }\end{array}$ \\
\hline JOURNAL & "Banks and Bank Systems" \\
\hline ISSN PRINT & $1816-7403$ \\
\hline ISSN ONLINE & $1991-7074$ \\
\hline PUBLISHER & LLC "Consulting Publishing Company "Business Perspectives" \\
\hline FOUNDER & LLC "Consulting Publishing Company "Business Perspectives" \\
\hline
\end{tabular}

NUMBER OF REFERENCES

46

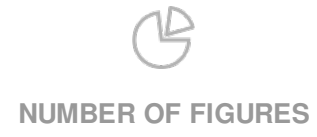

4
NUMBER OF TABLES

5

(C) The author(s) 2021. This publication is an open access article. 


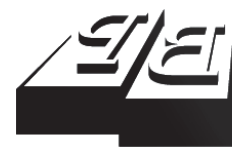

\section{BUSINESS PERSPECTIVES}

LLC "CPC "Business Perspectives" Hryhorii Skovoroda lane, 10, Sumy, 40022, Ukraine www.businessperspectives.org
Received on: $17^{\text {th }}$ of April, 2020 Accepted on: $1^{\text {st }}$ of June, 2020 Published on: $9^{\text {th }}$ of June, 2020

๑) Csaba Lentner, Vitéz Nagy, 2020

Csaba Lentner, Professor, CSC, Dr. habil. in Public Finance, Faculty of Public Governance and International Studies, National University of Public Service, Hungary. (Corresponding author)

Vitéz Nagy, Ph.D. student, Corvinus University of Budapest, Hungary.

\title{
NEW DIMENSIONS OF COMMERCIAL BANKS' CORPORATE SOCIAL RESPONSIBILITY IN THE VISEGRÁD GROUP COUNTRIES
}

\begin{abstract}
The study focuses on corporate social responsibility, which is of pivotal significance in the banking sectors of the countries of the so-called Visegrád Group, located in the Central European region and representing similar levels of economic development (V4). The aim of this paper is to examine the changes in the CSR activities of notable banks in the V4 countries between 2007, 2013 and 2018. The study consisted of three phases: first, it determined the relevant CSR goals based on the content (document) analysis; then, a questionnaire survey was conducted among banks for three years $(2007,2013,2018)$; and finally, the data were analyzed using variance analysis. As a result of the first phase, 15 CSR activities were identified, and as a result of a questionnaire survey, the focus of each CSR area was presented on a spider-web diagram showing a shift in the "priority order" of CSR areas and target groups, in other words, the intensification of activity towards social groups closer to the activities of banks or even clients. Using both qualitative and quantitative methods, this study confirmed with primary research that the focus of CSR activities in the V4 countries has shifted from general societal challenges to climate protection and the development of financial culture. These results were also evidenced by multivariate statistical methods proving a significant change in $66 \%$ of the examined areas.
\end{abstract}

Keywords

JEL Classification

\section{INTRODUCTION}

The crisis that set out from the Anglo-Saxon mortgage markets in 2007 was basically due to the lax lending policy of commercial banks, resulting in the allocation of amounts that exceeded debtors' creditworthiness. The supervisory authorities and national and international regulations decreasingly restricted the activities of commercial banks focusing on excessive profiteering. Moreover, the system of assuming corporate social responsibility by commercial banks was fundamentally different from their current practice. However, since the burst of the crisis, tighter requirements have been in place in both banking regulation and bank control, and what is more, CSR policies of commercial banks underwent transformations, as their views on the setting of priorities in assuming responsibility changed. This study analyzes the transformation of CSR policy in commercial banks and in the most significant financial institutions in the Central European region, and more specifically in the V4 countries, and draws relevant conclusions regarding this sector and the population of this region, fundamental political, social and economic changes occurred in the late 1980s. The countries of Central Europe broke away from the soviet system, left the planned economic structure behind, and entered the group of emerging market economies. 
These four countries (Czech Republic, Poland, Hungary, and Slovakia) have very similar histories and are on comparable economic levels despite Slovakia's accession to the euro area in 2009. The banking sectors of the analyzed countries were characterized by privatization and the spread of foreign banks. An empirical study conducted among commercial banks with a predominant role in the financial life of these four Central European countries between 2007 and 2018 can provide an appropriate basis for assessing their CSR policies, and since the parent banks' control is enforced, indirect conclusions can also be drawn about the CSR policies followed by banks in the euro area. Both before and after the crisis, the subsidiary banks operating in the V4 countries mapped the operating models of the respective parent banks in their business models and in CSR policies. Consequently, the CSR research conducted in Central European V4 countries may have a valid message to those interested in the banking system of the euro area.

The paper presents the results of a three-step study in which CSR areas of banks were examined by analyzing the CSR reports of banks using a document analysis method. They were investigated using a questionnaire survey conducted in 2007, 2013 and 2018. The answers were examined and conclusions were drawn using descriptive statistics and variance analysis.

\section{LITERATURE REVIEW AND HYPOTHESIS DEVELOPMENT}

The study of the concept of corporate social responsibility is very common in the literature. Several studies have examined the practical implementation of CSR activities. CSR activity is a complex phenomenon and has an increasing impact on business. As a rating requirement, generally accepted among corporations, the impact of their activities on their immediate and broader environment is assessed, which makes corporate social responsibility indispensable for creating a favorable investment environment (Kapstein, 2001).

CSR activity strengthens the reputation of organizations (Marom, 2006), increases customer loyalty and trust (Mohr, Webb, \& Harris, 2001), reduces business risks and, as a result, the cost of capital (Bassen, Meyer, \& Schlange, 2006). According to Sen and Bhattacharya (2001), CSR activity provides an opportunity to introduce new products and services and to exploit new markets. Many researchers (Vogel, 2006; Kotler \& Lee, 2007; Porter \& Kramer, 2002) have already formulated the concept of social responsibility; however, they all agree on the intertwining of economic and social goals. Sector-specific studies on CSR activities focus mainly on the banking and financial sector.

The consequences of the 2007-2008 crisis include the rise of social responsibility in prominence and, moreover, the rearrangement of their priority considerations in the banking sector. Numerous studies have examined the relationship between banks' social responsibility and financial performance. Research has confirmed that in the financial sector, CSR activity has a beneficial impact on demand, confidence and customer retention (Kaur, 2018; Platonova, Asutay, Dixon, \& Mohammad, 2018; Esteban-Sánchez, de la Cuesta-González, \& Paredes-Gazquez, 2017; M. Miralles-Quirós, J. Miralles-Quirós, \& Redondo-Hernández, 2019). According to Forcadell and Aracil (2017), CSR activities of banks have a positive effect on the performance of the banks and on establishing good reputation. Thematic priorities of the financial sector include ethics and maintaining the transparency, and this sector has a significant impact on the country's economic development (Azim, 2011). Financial institutions pay more attention to improving the financial culture and financial literacy of the population (Kovács \& Terták, 2019). However, the CSR policy applied in the banking sector remains contradictory, since the banking sector is often considered as an amoral area primarily focusing on risks and revenues (Caliskan, Icke, \& Ayturk, 2011). The operation of a bank is predictable if its financial situation is stable, its activity is ethical and transparent, and its economic performance increases, thus providing it the opportunity to understand and support social demand. In the course of their CSR activities, banks primarily focus on the working conditions of their employees, but they also endeavor to improve the bank's short-term image and increase its profits 
(Pérez \& Del Bosque, 2012). However, in terms of bank profitability, it should also be emphasized that employee qualification and the incentives facilitating employee retention and increase in employee performance are non-negligible considerations (Giannarakis, Konteos, Zafeiriou, \& Partalidou, 2016).

Financial institutions recognized the significance of CSR activities relatively late, and initially they only focused on environmental and wildlife areas, but later on responsibility for the society also evolved (Viganò, \& Nicolai, 2009). A CSR tool that has emerged in the banking sector can improve economic performance and manifests business ethical principles of this activity (Scholtens, 2006). Social responsibility can increase corporate profit and moderate reputational risks (Heal, 2005).

Aguilera, Rupp, Williams, and Ganapathi (2007) emphasize that the CSR policy of a company heavily depends on the approach to its employees. The environmental policy also confirms that support to employees is indispensable to ensure CSR policies (Ramus \& Steger, 2000). Meanwhile, employees, as an interest group, evaluate CSR activities and respond to them (Rupp, Ganapathi, Aguilera, \& Williams, 2006). Numerous studies have analyzed the impact of CSR activities on employee commitment (Duthler \& Dhanesh, 2018; Lin \& Liu, 2017; Chaudhary, 2017; Kim, Song, \& Lee, 2016; Barakat, Isabella, Boaventura, \& Mazzon, 2016; Mehralian, Nazari, Zarei, \& Rasekh, 2016). Another study shed light on the fact that banks' CSR activities did not merely focus on employee interest but also on various social groups (AlRazaq \& Shabaan, 2019; Hur, Moon, \& Ko, 2018; Stites \& Michael, 2011), however, developmental differences within the boundaries of the individual countries render the latter more difficult (Sági \& Engelberth, 2019). These trends of opening towards the wider society are increasingly manifested in the CSR policies of commercial banks.

In his CSR model, Carroll (1991) distinguishes four levels of responsibility, which will be applied to the banking sector. These four levels comprise economic responsibility, in other words, ensuring the owners' welfare, or profit maximization, through financial innovation as a means. Legal compliance includes both legal and ethical respon- sibility, and even commitment to engage in charity. Statutory compliance facilitates the reduction of risks to the minimum and improves confidence in the financial system. However, in addition to statutes, guidance by the various supervisory authorities and professional associations also needs to be taken into account (Decker \& Sale, 2009). In the financial sector, ethical responsibility manifests itself in fair conduct while ensuring transparent operation. On the other hand, Decker and Sale (2009) point out that statutory accountability and ethical responsibility do not always reinforce each other. Discretionary or philanthropic responsibility is widespread among banks and contributes to improving the given financial institution's good reputation. After the crisis, CSR activity of banks changed as demand for meeting social expectation gradually increased.

The requirements set by stakeholders affected by banks have also changed. The CSR and normative ethical theories of shareholders and stakeholders have a major impact on the operation of companies. It is the manager's responsibility to align the needs of stakeholders with the financial expectations of shareholders, even if it reduces shareholder returns (Smith, 2003). Managers are accountable to both the company's shareholders and stakeholders, so they must ensure that the rights of stakeholders are protected (Jones \& Wicks, 1999; Post, Preston, \& Sachs, 2002).

Clients are interested in receiving appropriate information and safe products, while employees require safe and non-discriminating workplaces and respect for human dignity. Raising awareness of financial decisions made by clients, especially households, thus developing predictable family finances, is both a direct and an indirect goal (Sági \& Juhász, 2019). Competitors require fair competition, and in a social perspective, help has come to the poor. Based on all these, banks are expected to voluntarily contribute to the solution of social problems and merely strive for corporate profit (Barclift, 2012). CSR activity should be built in daily operations and organizational culture of banks. Muslim banks are also aware of the importance of social responsibility, and this also manifests itself in the quality of services provided (AlRazaq \& Shabaan, 2019). According to Varga (2017), the Muslim banking system is more stable than tradi- 
tional "Western" banks, because they take higher responsibility towards clients and manage banking risks as the predominant features.

An additional new element that emerged in the period that followed the crisis was the re-definition of the role to be played by central banks in maintaining financial stability. This eroded significant amounts of public funds and required the use of extensive government resources. State budgets were influenced by economy boosting actions, the elimination of unemployment and bank rescue packages. The functions of central banks were reconsidered in Europe (also in respect of the European Central Bank) and in the United States (Naményi, 2012). Central banks also formulated their CSR strategies and activities. CSR comprises financial sustainability, stability-related duties, equal opportunities and environmental protection. Improvement in financial literacy, as well as education to facilitate the latter, have been added to expand the scope of these activities, and information for the users of financial services has been assigned outstanding significance (see for example the practice of Magyar Nemzeti Bank (National Bank of Hungary) and FED). Using their tools and proactive communication, central banks can influence opinions. Among the focal points in central banks' CSR activity are the improvement of financial literacy and proactive (positive) influence on society parallel with deepening financial education. Thus, overall, corporate social responsibility has come to the forefront in both commercial and central banking activities, and they mutually reinforce each other, but in the past 12 years their priority considerations have changed.

The purpose of this paper is to analyze (and underpin) the assumptions made in an earlier study relying on direct empirical findings (Lentner, 2013), which claim that the commercial banks' CSR policy shifted the emphasis to activities that fall closer to basic banking functions (lending and deposit policies), and that banks' corporate social responsibility is improved in relation to their specific bank clientele. In other words, the aim is to assess, using mathematical and statistical methods, developments related to priorities in various CSR areas, for key financial institutions of banking markets of particular countries, provided that they operate as independent Central European subsidiaries of the most important, large Western European banks, and to provide a stronger evidence than previous research could provide for the increasing role of CSR and the rearrangement of its considerations and target groups. The hypothesis of this study is that since the crisis, corporate social responsibility of banks has increased, and certain CSR areas have been significantly rearranged.

H1: Over the past 10 years, CSR policies of commercial banks have shifted significantly towards improving general financial literacy.

\section{DATA AND METHODOLOGY}

The analysis includes a specification of the key large banks in the euro area, which established significant business interests in the V4 region, had already been functioning during the 2007-2008 crisis and are still operating in the region. Five continuously operating banks were analyzed in each country. Only banks of a key significance in the host national markets were included. In addition to the selection criteria, the analysis of the combined effect of several additional factors also preceded inclusion in the sample. In other words, "key significance" was only acknowledged if several conditions were met simultaneously, in particular, criteria related to economic data (balance-sheet total, the volume of allocated loans, interest revenue and the loan-to-deposit ratio), social factors (branch network in a country and the nature and size of the clientele), and the measurability of social impact, especially CSR activities, i.e., the predominant role in the functioning of a particular national economy. As a characteristic feature, the operation of the analyzed financial institutions was uninterrupted during the entire period (20072018). To give the best possible representation, a key criterion for choosing the five banks in the sample was that in the reporting period, the bank should continuously have a balance-sheet total exceeding 10 per cent of the aggregate balance-sheet total of a particular country's commercial banking sector. It stands to reason that investment banks and multinational banks that have evolved in the region and have a major market share in any of the other analyzed countries, for example, the Hungarian OTP Bank, were not included in the analyzed sample. The sample can be considered 
Table 1. The sample

Source: The authors' research, 2020.

\begin{tabular}{|c|c|c|c|}
\hline Country & Number of banks analyzed & Number of commercial banks & Analyzed banks' ratio \\
\hline Poland & 5 & 55 & $9 \%$ \\
\hline Czech Republic & 5 & 25 & $20 \%$ \\
\hline Slovakia & 5 & 15 & $33 \%$ \\
\hline Hungary & 5 & 30 & $17 \%$ \\
\hline Total & 20 & 125 & $16 \%$ \\
\hline
\end{tabular}

representative in terms of company size, ownership structure, as it includes in full the subsidiaries of parent banks in the Eurozone member country operating in the V4 countries.

Since the efforts to generate the so-called systemic and trend data were made during the disclosure of the analysis and its data, the individual banks and the characteristic features of their activities were not specified. Moreover, efforts were made to prevent guessing the identity of individual banks, as this would provide suggestions for their operation in the private market and an opportunity to conclude on evaluating the latter, which is beyond the scope of an objective academic study.

Interestingly enough, the periods of the subprime crisis, crisis management, recovery, pick-up and the subsequently evolved boom, which resulted in a measurable differentiation in CSR policies, were all included in the analyzed period.

Annual financial accounts, business reports and CSR policy documents of banks included in the sample for the purposes of the research were analyzed in addition to the evaluation of a classical questionnaire. Regarding the analyzed banks, the press releases and academic papers published by commercial banks in their media portfolios and on their public surfaces were also taken into account. Regarding commercial banks, in the course of analyzing a complex document and informa- tion, CSR areas that prevailed both during and after the initial years of the 2007-2008 crisis were determined, and new CSR areas were successfully identified. In this stage of the research, the method of document analysis was chosen, during which the contents of CSR reports and announcements were analyzed. During this process, the most common CSR activities for the three years examined were coded. The analysis revealed the following (15) specific CSR areas:

1. Climate protection activity.

2. Animal protection support (improved living conditions for protected species and abandoned pets, and similar charities).

3. Competitive sports support.

4. Support for cultural and artistic events and related creative activities.

5. Financing scientific research in abstract and natural sciences.

6. Financing academic research in social sciences and liberal arts.

7. Financing academic research in applied sciences.

8. Support for academic research in interdisciplinary areas.

Table 2. The research process and methodology

Source: The authors' research, 2020.

\begin{tabular}{|c|c|c|c|}
\hline Phase & Goal & Methodology & Result \\
\hline I. Document analysis (qualitative) & Identification of CSR & Content analysis & $\begin{array}{l}\text { Delimitation of } 15 \text { CSR } \\
\text { activities }\end{array}$ \\
\hline II. Conducting surveys $(2007,2013,2018)$ & $\begin{array}{l}\text { Providing primary data for } \\
\text { research }\end{array}$ & $\begin{array}{l}\text { Structured, self- } \\
\text { administered questionnaire }\end{array}$ & $\begin{array}{l}\text { Primary data and their } \\
\text { processing }\end{array}$ \\
\hline III. Data analysis (quantitative) & $\begin{array}{l}\text { Confirmation of the study } \\
\text { hypothesis }\end{array}$ & $\begin{array}{l}\text { Descriptive statistics, } \\
\text { analysis of variance, post- } \\
\text { hoc test }\end{array}$ & $\begin{array}{l}\text { Conclusion, hypothesis } \\
\text { assessment }\end{array}$ \\
\hline
\end{tabular}


9. Support for people living with disabilities, minorities or financially and socially disadvantaged people, their convergence and assistance.

10. Support for grassroots sports.

11. Improving financial literacy and financial awareness of secondary-school and higher-education students.

12. Programs to improve financial awareness of young couples and young people starting a career.

13. Awareness raising activities to facilitate familiarization with banking for bank customers (borrowers), credit counseling.

14. Banking and other financial counseling for start-ups and micro-businesses, and improving their financial literacy.

15. Complex support activity in the interest of complex improvement of financial awareness of the population, potential and the specific clientele.

In the course of reviewing the reports, the study specifically focuses on three years: 2007, 2013 and 2018 , i.e. the business years before and during the crisis, and the one after reorganizations. The significance of a particular CSR area was analyzed using a complex questionnaire test, with the help of the Likert scale (between 1 and 5). The responses and the data relating to the sources of information have been anonymized, as the persons who completed the forms (respondents) are irrelevant for the analysis, since the aim was not to analyze individual preferences but to detect changes in the CSR activity in the region.

The questionnaire was processed using descriptive statistical methods, and a radial chart was compiled to illustrate the changes. In addition to the radius diagram, variance analysis was used to explore significant differences in the responses of the 15 different areas. For the variables for which a significant difference was found, a post-hoc test was performed, the Scheffé test. The Scheffé test is a post-hoc test prevalent in social science practice that can identify the difference between the values of each dependent variable. While the variance detects the difference, the post-hoc test reveals the differences in pairs for each dependent variable and the independent variable (in this case, the year). The essence of the Scheffé test is to make pairwise comparisons for all possible combinations of means (averages). In doing so, it uses the sample distribution of the F-test, making it the most reliable test. The quantitative analysis was performed using MS Office and SPSS software packages.

\section{RESULTS}

During the analysis, the following summary tables were compiled with findings concerning 2007, the year preceding the European crisis, the interim year 2013 and the business year 2018 (Table 3).

Table 3 shows the average and the modus of the responses, as well as the code of variables comprising a serial number (see the list of CSR areas) and the year when the questionnaire was completed. The data reveal that in the years preceding the crisis, support for animal protection, competition sports, culture and arts scored the highest. In other words, CSR focused on these areas in the period reviewed (between 2007 and 2018). Support for research activity, comprising various disciplines, was of medium significance, as was the medium significance attached to climate protection in banking practice. As averages and modus values show, improving financial literacy and financial awareness were among the least emphatic areas prior to the crisis.

The findings of the 2013 survey suggest that the CSR areas have become more balanced. During personal interviews, it also became clear that the budgets of the activities had slightly decreased due to the crisis. Table 3 reveals that the areas considered as the most important in the previous survey, such as animal protection, support for culture and financing competition sports, have dropped in 2007. Simultaneously, a considerable increase is seen in the significance of climate protection and improving financial literacy, previously considered less important for support. Support for academic work, identified as an area of medium sig- 
Table 3. CSR survey, 2007

Source: The authors' research, 2020

\begin{tabular}{|c|c|c|c|c|c|c|}
\hline \multirow{2}{*}{ Variable } & \multicolumn{3}{|c|}{ Mean } & \multicolumn{3}{|c|}{ Mode } \\
\hline & 2007 & 2013 & 2018 & 2007 & 2013 & 2018 \\
\hline 1. Climate change & 3.8 & 4.2 & 4.8 & 3 & 4 & 5 \\
\hline 2. Animal protection & 4.3 & 3.8 & 3.4 & 4 & 4 & 3 \\
\hline 3. Competitive sports & 4.3 & 3.7 & 3.1 & 4 & 3 & 3 \\
\hline 4. Financing culture and arts & 4.4 & 3.7 & 3.2 & 4 & 3 & 3 \\
\hline 5. Research in natural sciences & 3.8 & 3.9 & 3.9 & 4 & 3 & 3 \\
\hline 6. Research in social sciences and liberal arts & 3.6 & 3.6 & 3.6 & 3 & 3 & 3 \\
\hline 7. Research in applied sciences & 3.7 & 3.6 & 3.8 & 3 & 3 & 3 \\
\hline 8. Research in interdisciplinary sciences & 3.5 & 3.5 & 3.6 & 3 & 3 & 3 \\
\hline 9. Support for disadvantaged social groups & 3.7 & 3.8 & 3.8 & 3 & 3 & 3 \\
\hline 10. Grassroots sports & 3.7 & 3.6 & 3.7 & 3 & 3 & 3 \\
\hline 11. Financial literacy, secondary school students & 3.2 & 3.5 & 3.8 & 3 & 3 & 4 \\
\hline 12. Financial literacy, young married couples, entrants & 2.7 & 3.5 & 4.6 & 2 & 3 & 5 \\
\hline 13. Financial literacy, borrowers & 2.8 & 3.7 & 4.6 & 3 & 4 & 5 \\
\hline 14. Financial literacy, SMEs & 2.5 & 3.3 & 4.8 & 2 & 3 & 5 \\
\hline 15. Financial literacy, households & 2.9 & 3.5 & 4.7 & 2 & 3 & 5 \\
\hline
\end{tabular}

nificance in the previous survey, has not changed considerably, and in some cases, a fall in the significance of this area can be observed.

In the 2018 survey, climate protection clearly has a key significance, which manifests itself in the elaboration of grants in aid, on the one hand, and more favorable loan schemes, on the other. The efforts made to improve financial literacy and awareness among various economic stakeholders, including young couples, career starters, borrower SMEs and households, have further increased in CSR. In contrast, certain areas that used to be key before the crisis, such as support for competitive sports and culture and art, considerably dropped in importance. Banks' efforts to improve the young generation's financial awareness also increased but remained less important than other areas of financial awareness. The significance of research and development has not changed considerably over the three periods under review, and in the last evaluated year, its importance exceeded the average. The changes made in the three years reviewed are depicted in radial charts. They include variable codes and average values.

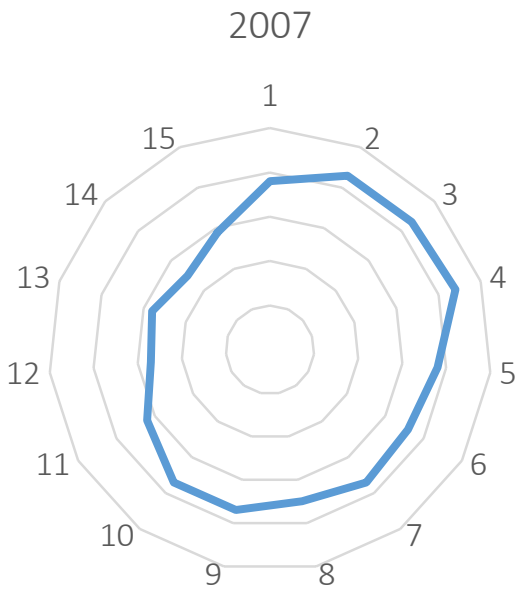

Figure 1. Radial chart of changes in CSR objectives (2007) 


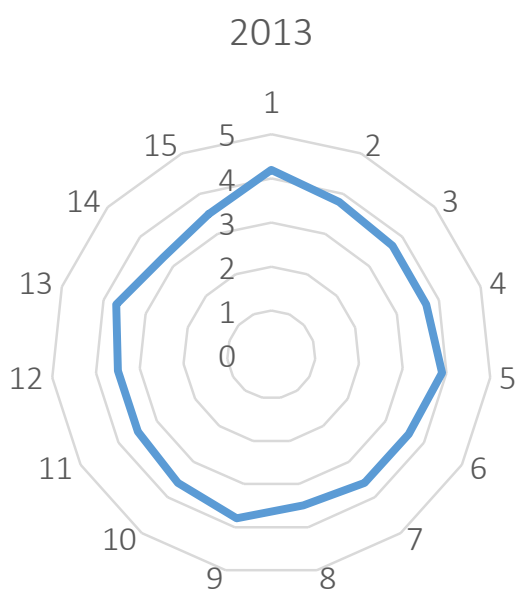

Source: The authors' research, 2020.

Figure 2. Radial chart of changes in CSR objectives (2013)

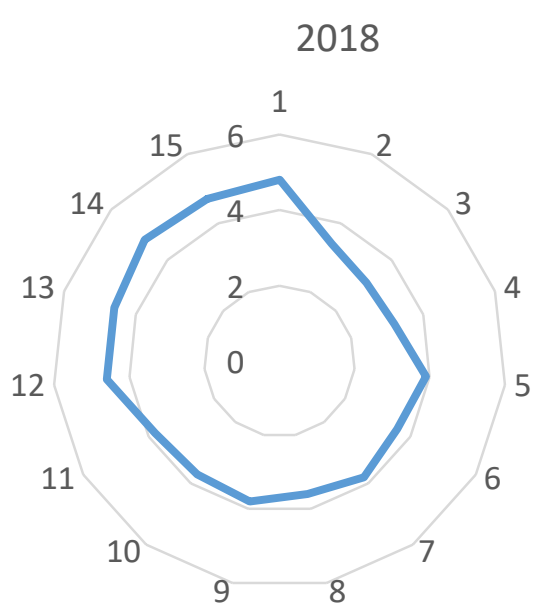

Source: The authors' research, 2020.

Figure 3. Radial chart of changes in CSR objectives (2018)

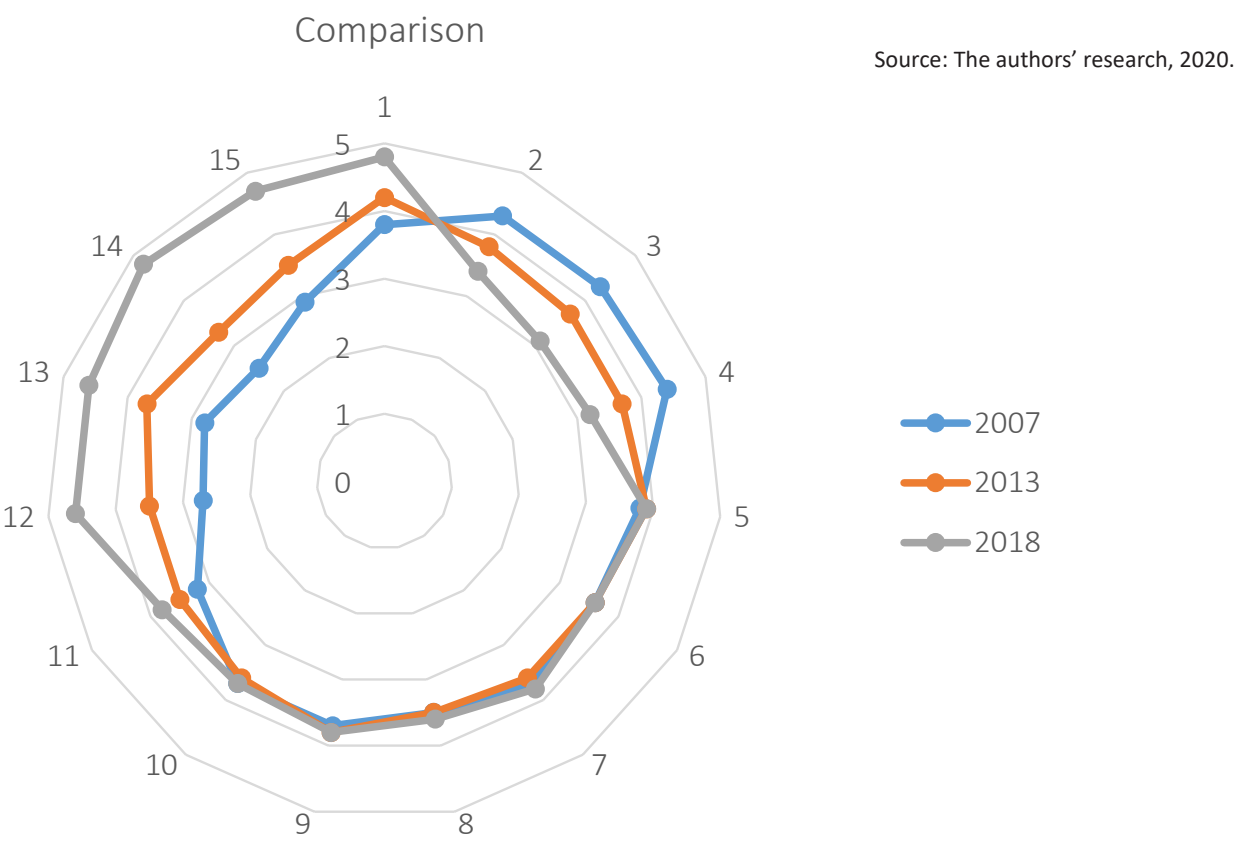

Figure 4. Radial chart of changes in CSR objectives (2007-2018) 
Table 4. Variance analysis results

Source: The authors' research, 2020

\begin{tabular}{|c|c|c|c|c|c|c|}
\hline \multicolumn{7}{|c|}{ ANOVA } \\
\hline & & $\begin{array}{l}\text { Sum of } \\
\text { squares }\end{array}$ & df & Mean square & $\mathbf{F}$ & Sig. \\
\hline \multirow{3}{*}{ Climate change } & Between groups & 10.133 & 2 & 5.067 & 57.530 & .000 \\
\hline & Within groups & 5.020 & 57 & .088 & - & - \\
\hline & Total & 15.153 & 59 & - & - & - \\
\hline \multirow{3}{*}{ Animal protection } & Between groups & 8.321 & 2 & 4.161 & 919.217 & .000 \\
\hline & Within groups & .258 & 57 & .005 & - & - \\
\hline & Total & 8.579 & 59 & - & - & - \\
\hline \multirow{3}{*}{ Competitive sports } & Between groups & 14.550 & 2 & 7.275 & 32.810 & .000 \\
\hline & Within groups & 12.639 & 57 & .222 & - & - \\
\hline & Total & 27.189 & 59 & - & - & - \\
\hline \multirow{3}{*}{ Financing culture and arts } & Between groups & 14.032 & 2 & 7.016 & 182.442 & .000 \\
\hline & Within groups & 2.192 & 57 & .038 & - & - \\
\hline & Total & 16.224 & 59 & - & - & - \\
\hline \multirow{3}{*}{ Research in natural sciences } & Between groups & .309 & 2 & .155 & 3.452 & .038 \\
\hline & Within groups & 2.551 & 57 & .045 & - & - \\
\hline & Total & 2.860 & 59 & - & - & - \\
\hline \multirow{3}{*}{$\begin{array}{l}\text { Research in social sciences } \\
\text { and liberal arts }\end{array}$} & Between groups & .000 & 2 & .000 & .000 & 1.000 \\
\hline & Within groups & 8.420 & 57 & .148 & - & - \\
\hline & Total & 8.420 & 59 & - & - & - \\
\hline \multirow{3}{*}{ Research in applied sciences } & Between groups & .433 & 2 & .217 & 3.519 & .056 \\
\hline & Within groups & 3.510 & 57 & .062 & - & - \\
\hline & Total & 3.943 & 59 & - & - & - \\
\hline \multirow{3}{*}{$\begin{array}{l}\text { Research in interdisciplinary } \\
\text { sciences }\end{array}$} & Between groups & .133 & 2 & .067 & .360 & .699 \\
\hline & Within groups & 10.560 & 57 & .185 & - & - \\
\hline & Total & 10.693 & 59 & - & - & - \\
\hline \multirow{3}{*}{$\begin{array}{l}\text { Support for disadvantaged } \\
\text { social groups }\end{array}$} & Between groups & .096 & 2 & .048 & .293 & .747 \\
\hline & Within groups & 9.366 & 57 & .164 & - & - \\
\hline & Total & 9.462 & 59 & - & - & - \\
\hline \multirow{3}{*}{ Grassroots sports } & Between groups & .300 & 2 & .150 & 1.023 & .366 \\
\hline & Within groups & 8.360 & 57 & .147 & - & - \\
\hline & Total & 8.660 & 59 & - & - & - \\
\hline \multirow{3}{*}{$\begin{array}{l}\text { Financial literacy, secondary } \\
\text { school students }\end{array}$} & Between groups & 3.600 & 2 & 1.800 & 10.281 & .000 \\
\hline & Within groups & 9.980 & 57 & .175 & - & - \\
\hline & Total & 13.580 & 59 & - & - & - \\
\hline \multirow{3}{*}{$\begin{array}{l}\text { Financial literacy, young } \\
\text { married couples, entrants }\end{array}$} & Between groups & 35.269 & 2 & 17.635 & 41.109 & .000 \\
\hline & Within groups & 24.451 & 57 & .429 & - & - \\
\hline & Total & 59.720 & 59 & - & - & - \\
\hline \multirow{3}{*}{ Financial literacy, borrowers } & Between groups & 32.400 & 2 & 16.200 & 1282.500 & .000 \\
\hline & Within groups & .720 & 57 & .013 & - & - \\
\hline & Total & 33.120 & 59 & - & - & - \\
\hline \multirow{3}{*}{ Financial literacy, SMEs } & Between groups & 54.676 & 2 & 27.338 & 78.600 & .000 \\
\hline & Within groups & 19.826 & 57 & .348 & - & - \\
\hline & Total & 74.502 & 59 & - & - & - \\
\hline \multirow{3}{*}{$\begin{array}{l}\text { Financial literacy, } \\
\text { households }\end{array}$} & Between groups & 33.249 & 2 & 16.625 & 89.333 & .000 \\
\hline & Within groups & 10.608 & 57 & .186 & - & - \\
\hline & Total & 43.857 & 59 & - & - & - \\
\hline
\end{tabular}

Figures 1-3, generated from Tables 1-3 and, sum- by 2013 the target groups became more balanced marized in Figure 4, clearly show rearrangements and the various areas aligned, as clearly shown in key CSR areas and their evolution over time. in Figure 2. However, the CSR activities of large While in 2007 the aim was to increase the level of banks surveyed in 2018 clearly shifted towards ficomprehensive (general or overall) social welfare, nancial awareness and literacy, while climate pro- 
tection also remained a priority area, along with a downturn in several other fields previously considered key areas.

The three different surveys (2007, 2013, and 2018) provide a good basis for examining if there is a significant difference between the CSR attitudes of responding banks. The data for these three years can be classified as significantly different if the significance level of the F-test is lower than 0.05 (5\%), which is shown in bold in Table 4 . For 10 of the 15 studied variables, CSR activity can be stated to differ from each other depending on the significance level of the F-test. Thus, it can be concluded that there is a significant difference between the average values of respondents in: climate change, animal protection, competitive sports, financing culture and arts, research in natural sciences, financial literacy, secondary school students, financial literacy, young married couples, entrants, financial literacy, borrowers, financial literacy, SMEs, financial literacy, and households. The null hypothesis was rejected for these variables, given the significance level of the F-test.

On the other hand, the null hypothesis was accepted, and thus, there is no significant difference be- tween: research in social sciences and liberal arts, research in applied sciences, research in interdisciplinary sciences, support for disadvantaged social groups, grassroots sports.

Variance analysis reveals which variables show a significant difference, but does not give an answer as to which years differ from each other in the variables. The Scheffé test serves to study this.

In Table 5, the variables are marked in bold for each year where the test revealed a significant difference. According to the table, for a significant part of variables, each year differs significantly from each other. Therefore, the findings in Figures 1-3 can be statistically substantiated. In the case of the variable 'Research in natural sciences', not a single year differs significantly from each other, while in the case of the variable 'Financial literacy, secondary school students', the result of 2013 does not differ significantly from the other two years, while in the case of 2007 and 2018, a significant difference is observed. Thus, it can be deducted from the data that significant changes can be observed among these variables: climate change, animal protec-

Table 5. Scheffé test results

Source: The authors' research, 2020.

\begin{tabular}{|c|c|c|c|c|c|c|c|}
\hline \multicolumn{8}{|c|}{ Multiple comparisons } \\
\hline \multirow{3}{*}{ Dependent variable } & & & Scheffe & est & & & \\
\hline & \multirow{2}{*}{ (I) year } & \multirow{2}{*}{ (J) year } & \multirow{2}{*}{$\begin{array}{c}\text { Mean } \\
\text { difference } \\
(I-J)\end{array}$} & \multirow[b]{2}{*}{ Std. error } & \multirow{2}{*}{ Sig. } & \multicolumn{2}{|c|}{ 95\% confidence interval } \\
\hline & & & & & & Lower bound & Upper bound \\
\hline \multirow{6}{*}{ Climate change } & \multirow{2}{*}{2007} & 2013 & $-.4000^{*}$ & .0938 & .000 & -.636 & -.164 \\
\hline & & 2018 & $-1.0000^{*}$ & .0938 & .000 & -1.236 & -.764 \\
\hline & \multirow{2}{*}{2013} & 2007 & $.4000^{*}$ & .0938 & .000 & .164 & .636 \\
\hline & & 2018 & $-.6000^{*}$ & .0938 & .000 & -.836 & -.364 \\
\hline & \multirow{2}{*}{2018} & 2007 & $1.0000^{*}$ & .0938 & .000 & .764 & 1.236 \\
\hline & & 2013 & $.6000^{*}$ & .0938 & .000 & .364 & .836 \\
\hline \multirow{6}{*}{ Animal protection } & \multirow{2}{*}{2007} & 2013 & $.5100^{*}$ & .0213 & .000 & .457 & .563 \\
\hline & & 2018 & $.9100^{*}$ & .0213 & .000 & .857 & .963 \\
\hline & \multirow{2}{*}{2013} & 2007 & $-.5100^{*}$ & .0213 & .000 & -.563 & -.457 \\
\hline & & 2018 & $.4000^{*}$ & .0213 & .000 & .347 & .453 \\
\hline & \multirow{2}{*}{2018} & 2007 & $-.9100^{*}$ & .0213 & .000 & -.963 & -.857 \\
\hline & & 2013 & $-.4000^{*}$ & .0213 & .000 & -.453 & -.347 \\
\hline \multirow{6}{*}{ Competitive sports } & \multirow{2}{*}{2007} & 2013 & $.5550^{*}$ & .1489 & .002 & .181 & .929 \\
\hline & & 2018 & $1.2050^{*}$ & .1489 & .000 & .831 & 1.579 \\
\hline & \multirow{2}{*}{2013} & 2007 & $-.5550^{*}$ & .1489 & .002 & -.929 & -.181 \\
\hline & & 2018 & $.6500^{*}$ & .1489 & .000 & .276 & 1.024 \\
\hline & \multirow{2}{*}{2018} & 2007 & $-1.2050^{*}$ & .1489 & .000 & -1.579 & -.831 \\
\hline & & 2013 & $-.6500^{*}$ & .1489 & .000 & -1.024 & -.276 \\
\hline
\end{tabular}


Table 5 (cont.). Scheffé test results

\begin{tabular}{|c|c|c|c|c|c|c|c|}
\hline \multicolumn{8}{|c|}{ Multiple comparisons } \\
\hline \multirow[b]{3}{*}{ Dependent variable } & & & Scheff & est & & & \\
\hline & \multirow{2}{*}{ (I) year } & \multirow[b]{2}{*}{ (J) year } & \multirow{2}{*}{$\begin{array}{c}\text { Mean } \\
\text { difference } \\
(I-J)\end{array}$} & \multirow[b]{2}{*}{ Std. error } & \multirow[b]{2}{*}{ Sig. } & \multicolumn{2}{|c|}{ 95\% confidence interval } \\
\hline & & & & & & Lower bound & Upper bound \\
\hline \multirow{6}{*}{ Financing culture and arts } & \multirow{2}{*}{2007} & 2013 & $.6800^{*}$ & .0620 & .000 & .524 & .836 \\
\hline & & 2018 & $1.1800^{*}$ & .0620 & .000 & 1.024 & 1.336 \\
\hline & \multirow{2}{*}{2013} & 2007 & $-.6800^{*}$ & .0620 & .000 & -.836 & -.524 \\
\hline & & 2018 & $.5000^{*}$ & .0620 & .000 & .344 & .656 \\
\hline & \multirow{2}{*}{2018} & 2007 & $-1.1800^{*}$ & .0620 & .000 & -1.336 & -1.024 \\
\hline & & 2013 & $-.5000^{*}$ & .0620 & .000 & -.656 & -.344 \\
\hline \multirow{6}{*}{ Research in natural sciences } & \multirow{2}{*}{2007} & 2013 & -.1650 & .0669 & .056 & -.333 & .003 \\
\hline & & 2018 & -.1350 & .0669 & .140 & -.303 & .033 \\
\hline & \multirow{2}{*}{2013} & 2007 & .1650 & .0669 & .056 & -.003 & .333 \\
\hline & & 2018 & .0300 & .0669 & .905 & -.138 & .198 \\
\hline & \multirow{2}{*}{2018} & 2007 & .1350 & .0669 & .140 & -.033 & .303 \\
\hline & & 2013 & -.0300 & .0669 & .905 & -.198 & .138 \\
\hline \multirow{6}{*}{$\begin{array}{l}\text { Financial literacy, secondary } \\
\text { school students }\end{array}$} & \multirow{2}{*}{2007} & 2013 & -.3000 & .1323 & .085 & -.633 & .033 \\
\hline & & 2018 & $-.6000^{*}$ & .1323 & .000 & -.933 & -.267 \\
\hline & \multirow{2}{*}{2013} & 2007 & .3000 & .1323 & .085 & -.033 & .633 \\
\hline & & 2018 & -.3000 & .1323 & .085 & -.633 & .033 \\
\hline & \multirow{2}{*}{2018} & 2007 & $.6000^{*}$ & .1323 & .000 & .267 & .933 \\
\hline & & 2013 & .3000 & .1323 & .085 & -.033 & .633 \\
\hline \multirow{6}{*}{$\begin{array}{l}\text { Financial literacy, young } \\
\text { married couples, entrants }\end{array}$} & \multirow{2}{*}{2007} & 2013 & $-.7850^{*}$ & .2071 & .002 & -1.306 & -.264 \\
\hline & & 2018 & $-1.8700^{*}$ & .2071 & .000 & -2.391 & -1.349 \\
\hline & 2013 & 2007 & $.7850^{*}$ & .2071 & .002 & .264 & 1.306 \\
\hline & 2013 & 2018 & $-1.0850^{*}$ & .2071 & .000 & -1.606 & -.564 \\
\hline & & 2007 & $1.8700^{*}$ & .2071 & .000 & 1.349 & 2.391 \\
\hline & 2018 & 2013 & $1.0850^{*}$ & .2071 & .000 & .564 & 1.606 \\
\hline & & 2013 & $-.9000^{*}$ & .0355 & .000 & -.989 & -.811 \\
\hline & 2007 & 2018 & $-1.8000^{*}$ & .0355 & .000 & -1.889 & -1.711 \\
\hline & 2013 & 2007 & $.9000^{*}$ & .0355 & .000 & .811 & .989 \\
\hline Financial IIteracy, borrowers & 2013 & 2018 & $-.9000^{*}$ & .0355 & .000 & -.989 & -.811 \\
\hline & 2018 & 2007 & $1.8000^{*}$ & .0355 & .000 & 1.711 & 1.889 \\
\hline & 2018 & 2013 & $.9000^{*}$ & .0355 & .000 & .811 & .989 \\
\hline & & 2013 & $-.7850^{*}$ & .1865 & .000 & -1.254 & -.316 \\
\hline & 2007 & 2018 & $-2.3000^{\circ}$ & .1865 & .000 & -2.769 & -1.831 \\
\hline Finencidlitaroc cMac & 2012 & 2007 & $.7850^{\circ}$ & .1865 & .000 & .316 & 1.254 \\
\hline Financial IIteracy, sIVIES & 2013 & 2018 & $-1.5150^{*}$ & .1865 & .000 & -1.984 & -1.046 \\
\hline & 2018 & 2007 & $2.3000^{*}$ & .1865 & .000 & 1.831 & 2.769 \\
\hline & 2018 & 2013 & $1.5150^{*}$ & .1865 & .000 & 1.046 & 1.984 \\
\hline & & 2013 & $-.5700^{*}$ & .1364 & .000 & -.913 & -.227 \\
\hline & 2007 & 2018 & $-1.7850^{*}$ & .1364 & .000 & -2.128 & -1.442 \\
\hline Financial literacy, & 2013 & 2007 & $.5700^{*}$ & .1364 & .000 & .227 & .913 \\
\hline households & 2013 & 2018 & $-1.2150^{*}$ & .1364 & .000 & -1.558 & -.872 \\
\hline & 2018 & 2007 & $1.7850^{*}$ & .1364 & .000 & 1.442 & 2.128 \\
\hline & 2018 & 2013 & $1.2150^{*}$ & .1364 & .000 & .872 & 1.558 \\
\hline
\end{tabular}

Note: ${ }^{*}$ The mean difference is significant at the 0.05 level.

tion, competition sports, financing culture and arts, financial literacy, secondary school students, financial literacy, young married couples, entrants, financial literacy, borrowers, financial literacy, SMEs, financial literacy, households.

\section{DISCUSSION}

The study confirmed that climate change and the role of banks in the development of financial literacy have intensified significantly. At the same time, 
in V4 countries there is a verifiable decrease in banks' CSR activity related to animal protection. The analysis revealed that the focus of banking CSR in ensuring financial literacy and in line with general societal challenges has shifted to climate protection, which is expressed as a general expectation for all businesses. Banks have an important role to play in supporting environmental investments and providing incentives through financial conditionality. Financial literacy caused a number of problems in the region, in particular with the recovery of foreign currency lending. The banking system is favorable for those social groups who can be potential customers, and it is important to be able to make responsible decisions, increasing their financial literacy, as this will have a positive effect on their own management and, at the same time, on banking management.

Given the results of this study, it can be established that in the past 12 years the focus of CSR has shifted towards education, because banks are also fundamentally interested in ensuring that economic stakeholders (actual or potential clients of banks) appropriately understand financial flows and risks to make reasonable decisions. All this is important to prevent the recurrence of the previously seen lending crisis in the region, in other words, to maintain stability in bank credit portfolios.
Thus, the study confirmed the preliminary hypothesis that as a result of the crisis, the CSR criteria became tighter, and the order of their priorities was rearranged. The CSR target areas, which are closer to the activities of banks and to providing conditions for operation as a going concern, have come to the forefront. Thus, the CSR policy has moved towards expanding the clientele through a more stable customer with higher financial literacy, which is an essential feature. Unfortunately, apart from the earlier study mentioned in the beginning of the paper (Lentner, 2013), similar studies were not conducted to make a comparison.

In addition to demonstrating a rearrangement among the 15 CSR areas, this study also intends to prove that due to the protracted crisis, the CSR policy shows a very close correlation with the enforcement of the principle of going concern (Zéman \& Lentner, 2018), both directly and indirectly. The reason for this phenomenon is that, as in other countries of the world, the commercial banking sectors of countries located in the region have received considerable support from the central budgets over the past decades to prevent mass bankruptcy. Therefore, successes in CSR policies can also be seen in enhancing compliance with the principle of going concern, and this may lead to the prevention of another state-financed consolidation to support banks.

\section{CONCLUSION}

Since the crisis, banks have made efforts to implement their CSR policies or their responsibility to society, for the most part, simply due to the quality of their clientele. This means that they improve the financial literacy and awareness of customers related to a bank (or potentially establishing relationship with the bank at a later stage), and they implement their corporate social policy through these people, starting with an individual and moving on to the general. This means that smooth operation of banks basically requires clients with financial literacy, financial awareness and forethought as key contributors to the banks' profitable business management. That said, it is true (and confirmed by the personal interviews) that a banking CSR policy, which is more sensitive to social issues, also improves the bank's image and market perceptions. However, this does not overshadow the essence of the mentioned additional business consideration, that is, the phenomenon of CSR wrapped in marketing, as the activities of banks contribute more to the efficient and uninterrupted support of various social groups.

The study confirmed by scientific methodology that the focus of CSR activities of the subsidiaries of the Eurozone-resident large banks operating in the V4 countries changed after the crisis. While during the crisis general social goals were the supported areas, now post-crisis climate protection and the development of financial culture is the most important goals. We should learn a lesson from this, namely, banks have perceived an inadequate level of financial literacy in society, which negatively affects proper 
customer relations and, therefore, banking management and reputation, and also causes serious social problems. An increased focus on climate protection shows that financial institutions are well aware of global issues in which they want to play a more active role.

\section{AUTHOR CONTRIBUTIONS}

Conceptualization: Csaba Lentner.

Data curation: Vitéz Nagy.

Formal analysis: Vitéz Nagy.

Funding acquisition: Csaba Lentner.

Investigation: Csaba Lentner.

Methodology: Vitéz Nagy.

Project administration: Csaba Lentner.

Resources: Csaba Lentner.

Software: Vitéz Nagy.

Supervision: Vitéz Nagy.

Validation: Csaba Lentner, Vitéz Nagy.

Visualization: Vitéz Nagy.

Writing - original draft: Csaba Lentner.

Writing - review \& editing: Vitéz Nagy.

\section{REFERENCES}

1. Aguilera, R. V., Rupp, D. E., Williams, C. A., \& Ganapathi, J. (2007). Putting the back in Corporate Social Responsibility: A multilevel Theory of Social Change in Organizations. Academy of Management Review, 32(3), 836-863. https://doi.org/10.5465/ amr.2007.25275678

2. AlRazaq, H. A. \& Shabaan, F. (2019). Applications and Practices of Social Responsibility in Islamic Banks Presentation of Experiences. AL-Anbar University Journal of Economic and Administration Sciences, 11(25), 145-167. Retrieved from https://www.iasj.net/ iasj?func $=$ article $\&$ aId $=168105$

3. Azim, M., Ahmed, E., \& D’Nettó, B. (2011). Corporate Social Disclosure in Bangladesh: A Study of the Financial Sector. International Review of Business Research Papers, 7(2), 37-55. Retrieved from https://www.academia. edu/1940512/Corporate_Social_ Disclosure_in_Bangladesh_A_ Study_of_the_Financial_Sector

4. Barakat, S. R., Isabella, G., Boaventura, J. M. G., \& Mazzon, J. A. (2016). The Influence of Corporate Social Responsibility on
Employee Satisfaction. Management Decision, 54(9), 2325-2339. https://doi.org/10.1108/MD-052016-0308

5. Barclift, Z. J. (2012). Corporate Social Responsibility and Financial Institutions: Beyond Dodd-Frank. Banking \& Financial Services Policy Report, 31(1), 13-19. Retrieved from https://papers.ssrn. com/sol3/papers.cfm?abstract_ $\mathrm{id}=2232280$

6. Bassen, A., Meyer, K. \& Schlange, J. (2006). The influence of corporate responsibility on the cost of capital (An Empirical Analysis 2006). https://doi.org/10.2139/ ssrn.984406

7. Caliskan, E., Icke, B., \& Ayturk, Y. (2011). Corporate Reputation and Financial Performance: Evidence from Turkey. Research Journal of International Studies, 18, 61-72. Retrieved from https://www.academia.edu/14391925/Corporate_ Reputation_and_Financial_Performance_Evidence_from_Turkey

8. Carroll, A. B. (1991). The Pyramid of Corporate Social Responsibility: Toward the Moral Management of Organizational Stakeholders.
Business Horizons, 34(4), 39-48. https://doi.org/10.1016/00076813(91)90005-G

9. Chaudhary, R. (2017). Corporate Social Responsibility and Employee Engagement: Can CSR Help in Redressing the Engagement Gap? Social Responsibility Journal, 13(2), 323-338. https://doi.org/10.1108/ SRJ-07-2016-0115

10. Decker, S., \& Sale, C. (2009). An analysis of Corporate Social Responsibility, Trust and Reputation in the Banking Profession. In S. O. Idowu, \& W. L. Filho (Eds.), Professionals' Perspectives of Corporate Social Responsibility. Springer-Verlag Berlin Heidelberg. https://doi. org/10.1007/978-3-642-02630-0_8

11. Duthler, G., \& Dhanesh, G. S. (2018). The Role of Corporate Social Responsibility (CSR) and Internal CSR Communication in Predicting Employee Engagement: Perspectives from the United Arab Emirates (UAE). Public Relations Review, 44(4), 453-462. https://doi. org/10.1016/j.pubrev.2018.04.001

12. Esteban-Sánchez, P., de la CuestaGonzález, M., Paredes-Gazquez, J. D. (2017). Corporate social 
performance and its relation with corporate financial performance: International evidence in the banking industry. Journal of Cleaner Production, 162, 11021110. https://dx.doi.org/10.1016/j. jclepro.2017.06.127

13. Forcadell, F., \& Aracil, E. (2017) Reputation for European banks' corporate social responsibility. Corporate Social Responsibility and Environ-mental Management, 24(1), 1-14. https://doi. org/10.1002/csr.1402

14. Giannarakis, G., Konteos, G., Zafeiriou, E., \& Partalidou, X. (2016). The Impact of Corporate Social Responsibility on Financial Performance. Investment Management and Financial Innovations, 13(3), 171-182. https://doi.org/10.21511/ imfi.13(3-1).2016.03

15. Heal, G. (2005). Corporate Social Responsibility: An Economic and Financial Framework. The Geneva Papers on Risk and Insurance - Issues and Practice 30(3), 387-409. Retrieved from https:// link.springer.com/article/10.1057/ palgrave.gpp. 2510037

16. Hur, W. M., Moon, T. W., \& Ko, S. H. (2018). How Employees' Perceptions of CSR Increase Employee Creativity: Mediating Mechanisms of Compassion at Work and Intrinsic Motivation. Journal of Business Ethics, 153(3), 629-644. https://doi.org/10.1007/ s10551-016-3321-5

17. Jones, T. M., \& Wicks, A. C. (1999). Convergent stakeholder theory. Academy of Management Review, 24(2), 206-221. https://doi. org/10.2307/259075

18. Kapstein, E. B. (2001). The Corporate Ethics Crusade. Foreign Affairs, 80(5), 105-119. https://doi. org/10.2307/20050254

19. Kaur, S. (2018). A study on the Impact of CSR Performance on the Financial Performance of Indian Service Sector. International Journal of Business Competition and Growth, 6(2), 115-127. https://doi.org/10.1504/ IJBCG.2018.092435

20. Kim, J. S., Song, H. J., \& Lee, C. K. (2016). Effects of Corporate
Social Responsibility and Internal Marketing on Organizational Commitment and Turnover Intentions. International Journal of Hospitality Management, 55, 25-32. https://doi.org/10.1016/j. ijhm.2016.02.007

21. Kotler, P., \& Lee, N. (2005). Corporate Social Responsibility. John Wiley \& Sons, Inc. Retrieved from https://www.wiley.com/en-us/ Corporate+Social+Responsibility $\% 3 \mathrm{~A}+$ Doing+the + Most+Good + fo $\mathrm{r}+$ Your+Company+and + Your $+\mathrm{Ca}$ use-p-9780471476115

22. Kovacs, L., \& Tertak, E. (2019). Financial Literacy. Theory and Evidence. Verlag Dashöfer, vydavatel'stvo s.r.o. Bratislava, Slovakia. Retrieved from http:// bankszovetseg.hu/Public/publikacio/Financial\%20literacy.pdf

23. Lentner, Cs. (2013). A bankszabályozás tudományos rendszertana és fejlődéstörténete [Scientific Taxonomy and Development History of Bank regulation]. In Cs. Lentner (Ed.), Bankmenedzsment - Bankszabályozás - Pénzügyi fogyasztóvédelem [Bankmanagement - Bank regulation - Consumer Protection] (pp. 27-86). NKTK Publishing. Retrieved from https://www.researchgate.net/ publication/312491072_A_bankszabalyozas_tudomanyos_rendszertana_es_fejlodestortenete_I_fejezet

24. Lentner, Cs., Szegedi, K., \& Tatay, T. (2017). Social Responsibility in the Operation of Central Banks. Financial and Economic Review, 16(2), 64-85. https://doi. org/10.25201/fer.16.2.6485

25. Lin, C. P., \& Liu, M. L. (2017). Examining the Effects of Corporate Social Responsibility and Ethical Leadership on Turnover Intention. Personnel Review, 46(3), 526-550. https://doi.org/10.1108/PR-112015-0293

26. Marom, I. Y. (2006). Toward a unified theory of the CSP-CFP link. Journal of Business Ethics, 67(2), 191-200. https://doi.org/10.1007/ s10551-006-9023-7

27. Mehralian, G., Nazari, J. A., Zarei, L., \& Rasekh, H. R. (2016). The Effects of Corporate Social
Responsibility on Organizational Performance in the Iranian Pharmaceutical Industry: The Mediating Role of TQM. Journal of Cleaner Production, 135, 689698. https://doi.org/10.1016/j. jclepro.2016.06.116

28. Miralles-Quirós, M. M., Miralles-Quirós, J. L., \& RedondoHernández, J. (2019). The impact of environmental, social, and governance performance on stock prices: Evidence from the banking industry. Corporate Social Responsibility and Environmental Management, 26(6), 1446-1456. https://doi.org/10.1002/csr.1759

29. Mohr, L. A., Webb, D. J., \& Harris, K. E. (2001). Do consumers expect companies to be socially responsible? The impact of corporate social responsibility on buying behavior. The Journal of Consumer Affairs, 35(1), 45-72. https://doi. org/10.1111/j.1745-6606.2001. tb00102.x

30. Naményi, J. (2012). A pénzügyi válság hatása köz-ponti bankok szabályozására. Verseny és szabályozás [The Impact of the Financial Crisis on the Regulation of Central Banks. Competition and Regulation] (pp. 167-219). Research Centre for Economic and Regional Studies of the Hungarian Academy of Sciences.

31. Pérez, A., \& del Bosque, R. I. (2017). Personal Traits and Customer Responses to CSR Perceptions in the Banking Sector. International Journal of Bank Marketing, 35(1), 128-146. https://doi org/10.1108/IJBM-02-2016-0023

32. Platonova, E., Asutay, M., Dixon, R., \& Mohammad, S. (2018). The Impact of Corporate Social Responsibility Disclosure on Financial Performance: Evidence from the GCC Islamic Banking Sector. Journal of Business Ethics, 151(2), 451-471. https://doi.org/10.1007/ s10551-016-3229-0

33. Porter, M. E., \& Kramer, M. R. (2002). The Competitive Advantage of Corporate Philanthropy. Harvard Business Review, December. Retrieved from https://www. sharedvalue.org/sites/default/files/ resource-files/Competitive_Advantage.pdf 
34. Post, J. E., Preston, L. E., \& Sachs, S. (2002). Managing the extended enterprise: The new stakeholder view. California Management Review, 45(1), 5-28. https://doi. org/10.2307/41166151

35. Ramus, A. C., \& Steger, U. (2000). The Role of Supervisory Support Behaviors and Environmental Policy in Employee 'Ecoinitiatives' at Leading Edge European Companies. The Academy of Management Journal, 43(4), 605-626. Retrieved from https://www.jstor. org/stable/1556357

36. Rupp, D. E., Ganapathi, J., Aguilera, R. V., \& Williams, C. A (2006). Employee Reactions to Corporate Social Responsibility: An Organizational Justice Framework. Journal of Organizational Behavior, 27(4), 537-543. https:// doi.org/10.1002/job.380

37. Sági, J. \& Juhasz, P. (2019) Funding Alternatives and Business Planning in Family Businesses. Prosperitas, 6(1), 35-53. http://dx.doi.org/10.31570/ Prosp_2019_01_2
38. Sági, J., \& Engelberth, I. (2018). Regional Development and WellBeing of Regions in Hungary. Civic Review, 14(Special Issue), 184-194. https://doi.org/10.24307/ psz.2018.0412

39. Scholtens, B. (2006). Finance as a driver of corporate social responsibility. Journal of Business Ethics, 68(1), 19-33. https://doi. org/10.1007/s10551-006-9037-1

40. Sen, S., \& Bhattacharya, C. B. (2001). Does doing good always lead to doing better? Consumer reactions to corporate social responsibility. Journal of Marketing Research, 38(2), 225243. https://doi.org/10.1509/ jmkr.38.2.225.18838

41. Smith, H. J. (2003). The shareholders vs. stakeholders debate. MIT Sloan Management Review, 44(4), 85-90. Retrieved from https:// sloanreview.mit.edu/wp-content/ uploads/2003/07/b966946aae.pdf

42. Stites, J. P., \& Michael, J. H. (2011) Organizational Commitment in Manufacturing Employees: Relationships with Corporate Social Performance. Business \&
Society, 50(1), 50-70. https://doi. org/10.1177/0007650310394311

43. Varga, J. (2017). Az iszlám bankrendszer müködése [The Operation of Islamic Bank System]. Polgári Szemle - Civic Review, 13(1-3), 295-306. https://doi. org/10.24307/psz.2017.0925

44. Viganò, F., \& Nicolai, D. (2009). CSR in the European Banking Sector: Evidence from a Survey. In R. Barth, \& F. Wolff (Eds.), Corporate Social Responsibility in Europe: Rhetoric and Realities (pp. 95-108). Edward Elgar, Cheltenham. https://doi.org/ 10.4337/9781848447233.00017

45. Vogel, D. (2006). The Market for Virtue - The Potential and Limit of Corporate Social Responsibility. Brookings Institution Press, Washington, D. C.

46. Zeman, Z., \& Lentner, Cs. (2018). The Changing Role of Going Concern Assumption Supporting Management Decisions after Financial Crisis. Polish Journal of Management Studies, 18(1), 428-441. https://doi.org/10.17512/ pjms.2018.18.1.32 